American Journal of Environmental Sciences 5 (3): 455-460, 2009

ISSN 1553-345X

(C) 2009 Science Publications

\title{
Analysis of Water Properties and Geostrophic Currents in Fiji Waters Before and After Tropical Cyclone Gene
}

\author{
Shivneel Prasad, Than Aung and Awnesh Singh \\ Physics Division, University of the South Pacific, Laucala Campus, Suva, Fiji
}

\begin{abstract}
Problem statement: Water properties influence ocean primary production and drive the ocean food chain. This study depicts changes in temperature and salinity and its effects on geostrophic currents near Fiji before and after Tropical Cyclone (TC) Gene. Approach: Available Argo float data from 6 January-4 February 2008 were used for analysis since TC Gene passed the area on 28 January 2008. The dynamic height and geostrophic current data were obtained from the Aviso website. Results: The thermocline depth increased by $20 \mathrm{~m}$ after the cyclone. A temperature drop of approximately $3^{\circ} \mathrm{C}$ was also noticed in the study area. Using this drop in temperature, the heat energy removed by the cyclone was calculated to be $0.095 \mathrm{MWh} \mathrm{m}^{-2}$. Salinity profiles showed an increase of 0.42 psu to a depth of $35 \mathrm{~m}$ after the cyclone. Changes in salinity and temperature of water may also cause changes in the dynamic height and in turn the geostrophic current patterns. After plotting the geostrophic current vectors, it was observed that the current patterns changed significantly after TC gene. Seasonal changes were also evident before the cyclone. Conclusion/Recommendations: Although the lifespan of TC gene was short, its effect on the water properties near Fiji was significant as it completely changed the geostrophic current patterns and this can have a huge implication on marine life.
\end{abstract}

Keywords: Tropical cyclone, geostrophic currents, water properties, Fiji

\section{INTRODUCTION}

Natural extreme events such as cyclones, tsunamis, El Niño, etc., change the physical properties of ocean water such as salinity and temperature. Abrupt or slow changes in physical properties cause the dynamic behavior of the ocean to vary and may affect the geostrophic current patterns. Among these extreme events, Tropical Cyclones (TCs) with different strengths occur almost yearly in the South Pacific region between November and April.

A TC is a relatively small, intensely developed low pressure cell that usually occurs over warm oceans or a large cyclonic circulation over tropical waters. Its diameter can range between 200 and $2000 \mathrm{~km}$ and is characterized by a warm centre, very steep pressure gradients and strong cyclonic winds (clockwise in the southern hemisphere) near the Earth's surface. If TCs have maximum wind speed of less than $60 \mathrm{~km} \mathrm{~h}^{-1}$ they are called tropical depressions, when the maximum wind speed ranges between 60 and $120 \mathrm{~km} \mathrm{~h}^{-1}$, they are referred to as tropical storms and when the maximum wind speed exceeds $120 \mathrm{~km} \mathrm{~h}^{-1}$, they are classified as tropical cyclones. In the North Atlantic and eastern
North Pacific regions, they are called hurricanes, while in the western North Pacific they are called typhoons ${ }^{[2]}$.

Sea surface temperatures greater than $26^{\circ} \mathrm{C}$ are required for the formation of a cyclone, together with pre-existing low or high pressure, little wind shear with height and significant horizontal cyclonic shear. Tropical cyclones normally have a lifespan of less than two weeks. Owing to their destructive nature, TCs are actually an important mechanism, transporting excess amount of heat from the tropics to the poles and in the process, releasing vast amounts of energy daily. Robertson and Ginis ${ }^{[9]}$ stated that TCs affect the mixed layer salinity and temperature of the ocean. Salinity is affected by freshwater flux into the ocean and can also be affected by the wind stress of the TC on the ocean's surface.

Tropical cyclone gene: Tropical Cyclone Gene originated as a tropical depression north of the island of Futuna on 27 January 2008. The system moved southwest approaching the northeastern parts of Vanua Levu early on 28 January and followed a southwesterly track with the centre passing close to the southern coast of Vanua Levu between Savusavu and Nabouwalu.

Corresponding Author: Awnesh Singh, Physics Division, University of the South Pacific, Laucala Campus, Private Bag, Suva, Fiji Tel: 679-3232645 Fax: 679-3231511 


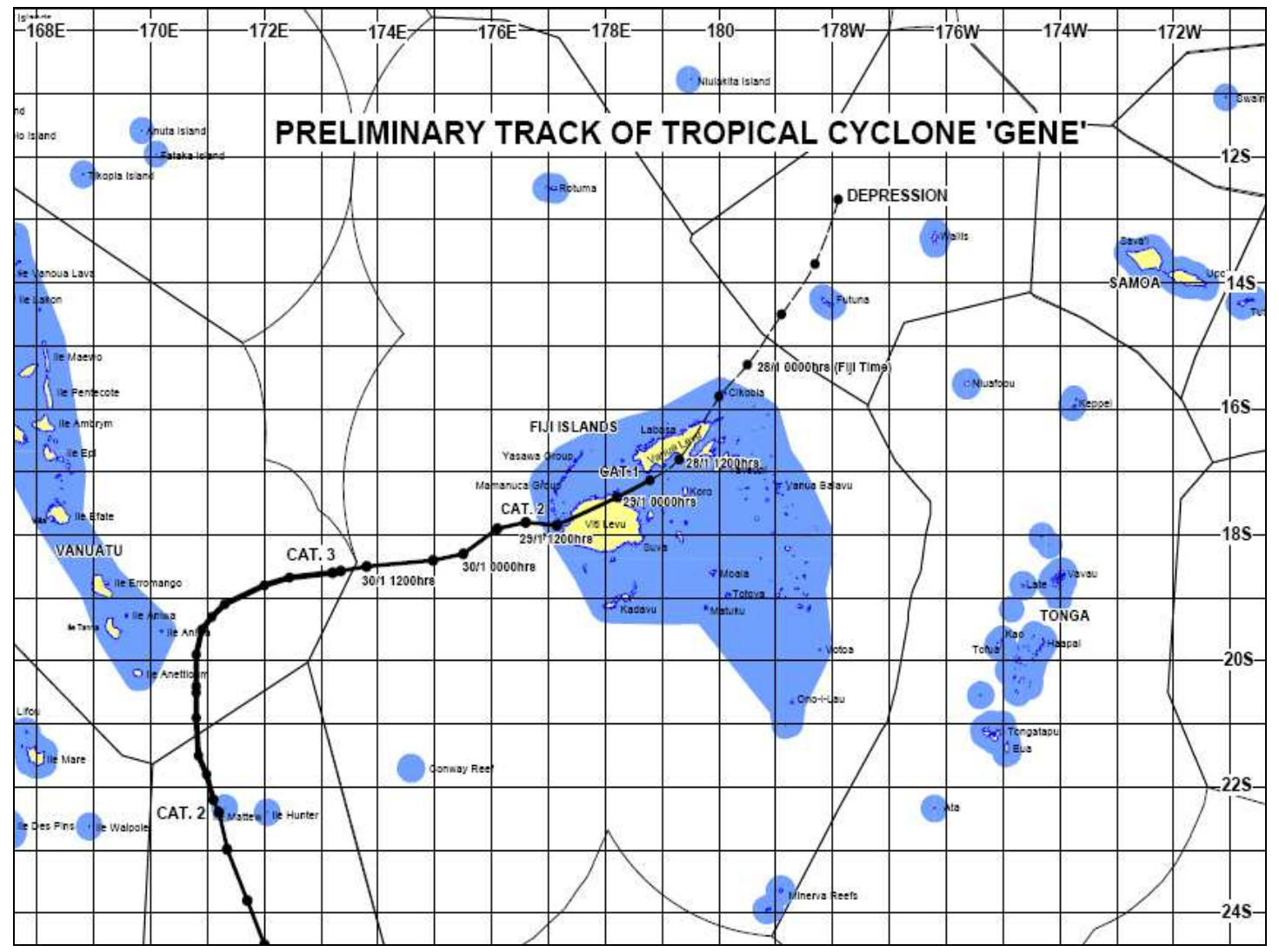

Fig. 1: Path of tropical cyclone gene near Fiji ${ }^{[4]}$

Around $6 \mathrm{pm}$ on 28 January, south of Vanua Levu (close to Nabouwalu), the system was named a tropical cyclone with $10 \mathrm{~min}$ average winds exceeding $65 \mathrm{~km} \mathrm{~h}^{-1[4]}$.

Tropical Cyclone Gene moved onto Viti Levu (main island in Fiji) with its low level centre passing over land overnight (Fig. 1) and during the early hours of 29 January. Figure 1 shows that the TC became more westerly intensifying as it moved away from Viti Levu.

The cyclone gained Category 2 status with destructive storm force winds early on 29 January and Category 3 status with very destructive hurricane force winds during the evening of 30 January. It intensified a little further but maintained its Category 3 status for about $18 \mathrm{~h}$ as the cyclone neared the southern islands of Tanna and Aneityum in Vanuatu. Tropical Cyclone Gene curved sharply southwards with its centre passing just east of Aneityum early on 1 February. Thereafter, it curved south-southeast and later southeast as it weakened slowly but maintained storm force winds for another three days before transforming into a depression well south of $\mathrm{Fiji}^{[4]}$.

\section{MATERIALS AND METHODS}

Different remote sensing systems were used to obtain data for this project. These include Argo float data, dynamic heights and geostrophic current velocities for the area near Fiji. Argo float data were acquired before and after TC Gene to obtain the salinity and temperature profiles from Coriolis website. Dynamic heights and geostrophic current velocities were obtained from the Aviso website to plot the topography and geostrophic velocity vectors.

Data collection: Data was obtained from four different Argo floats (Fig. 2) from 6 January-4 February 2008 in a square grid between latitudes 170 and $180^{\circ} \mathrm{E}$ and longitudes 15 and $21^{\circ} \mathrm{S}$ near the cyclone path. An Argo float measures salinity, temperature and pressure from the surface to $2000 \mathrm{~m}$ depth every ten days. The depth is calculated from pressure readings since one decibar is equivalent to $1 \mathrm{~m}$.

Figure 2 shows the location and movement of the selected float (float number 5900867), which lies in the path of the cyclone, over time. The distance of the float 
from Viti Levu was approximately $600 \mathrm{~km}$. Several other floats were available but they either did not have consistent data or were not near the path of the cyclone to show any significant changes of water properties. Argo float data was available on a 10 day interval since they complete one cycle of measurement and transmission within this time frame.

Heat energy transfer: In the upper layer of the ocean, temperatures decrease after a tropical cyclone has passed. This indicates that heat energy is being transported away from the tropics due to the cyclones movement towards the poles away from the equator. The amount of heat energy removed by a TC (per unit area) through the mixed layer can be calculated using Eq. 1:

$$
\frac{\Delta \mathrm{E}}{\mathrm{A}}=\rho \mathrm{lc} \Delta \mathrm{T}
$$

Where:

$$
\begin{aligned}
\frac{\Delta \mathrm{E}}{\mathrm{A}}= & \text { The heat energy } \mathrm{m}^{-2} \\
\rho \quad= & \text { The average density of seawater in the area } \\
& \left(1022 \mathrm{~kg} \mathrm{~m}^{-3}\right) \\
1= & \text { The depth of the mixed layer }(\mathrm{m}) \\
\mathrm{c}= & \text { The specific heat capacity of seawater }(3983 \\
& \left.\mathrm{J}^{\circ} \mathrm{C}^{-1} \mathrm{~kg}^{-1}\right) \\
\Delta \mathrm{T}= & \mathrm{The} \text { change in temperature }\left({ }^{\circ} \mathrm{C}\right) \text { before and after } \\
& \mathrm{a} \mathrm{TC} \mathrm{TC}^{[8]}
\end{aligned}
$$

Geostrophic currents: About $90 \%$ of ocean currents are geostrophic, which are usually computed from the measured salinity and temperature profiles by the geostrophic method ${ }^{[8]}$. The Earth's gravity acts to move water from areas of higher water levels (high pressure) to lower water levels (low pressure). The horizontal pressure difference can be best represented by a parameter called the dynamic height.

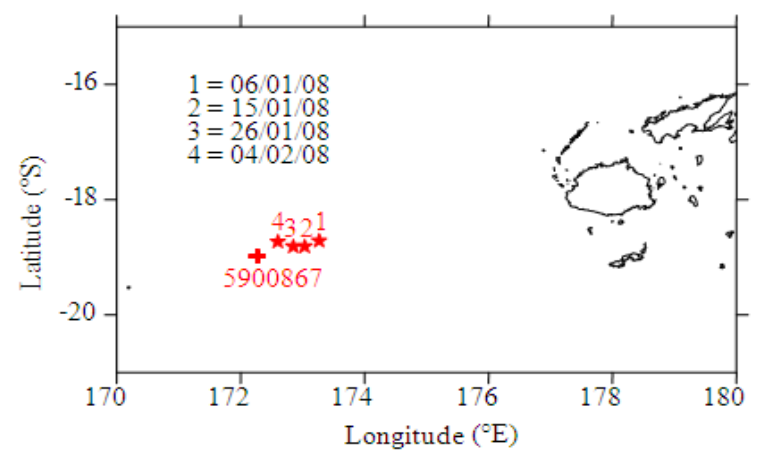

Fig. 2: Available float location near Fiji
Dynamic height is the vertical distance measured from a reference level, which is quantified in terms of changes in potential energy rather than distance and is usually measured in dynamic meters $(d y n-m)^{[1]}$. If the dynamic height is constant between two points, then the horizontal pressure gradient force is zero and hence there is no current, because the difference in dynamic heights gives rise to currents. When the pressure gradient force is balanced by the Coriolis force (due to the Earth's rotation), the current is said to be geostrophic. Equation 2 shows the balanced equation necessary for geostrophic currents:

$$
f v=\frac{1}{\rho} \frac{\partial p}{\partial x}
$$

Where:

f $\quad=$ The Coriolis parameter

$\mathrm{v}=$ The geostrophic current velocity

$\rho \quad=$ The density of seawater

$\frac{\partial \mathrm{p}}{\partial \mathrm{x}}=$ The horizontal pressure gradient

Geostrophic currents and dynamic height data were interpolated using Surfer software. A color plot of dynamic height was obtained and geostrophic current vectors were superimposed on it in this study.

\section{RESULTS AND DISCUSSION}

The average salinity and temperature for the surface layer were calculated using the data collected from the Argo floats. Table 1 below shows the average sea surface temperature (depth of $5 \mathrm{~m}$ ) before and after the cyclone.

Temperature profiles: The temperature data from the Argo float was used to plot temperature profiles before and after the cyclone and is shown in Fig. 3. Temperature readings were available to a depth of 2000 $\mathrm{m}$ but the main focus was on the mixed layer and the thermocline, which extended to a maximum depth of approximately $600 \mathrm{~m}$. Usually, temperature change in the deeper part is not significant.

Comparison of the mixed layer depth before and after TC Gene indicated that the mixed layer depth increases after the cyclone. The exact mixed layer depths for the respective dates are listed in Table 2.

Table 1: Surface temperature and salinity

\begin{tabular}{lll}
\hline Date & Temperature $\left({ }^{\circ} \mathrm{C}\right)$ & Salinity $(\mathrm{psu})$ \\
\hline $06 / 01 / 08$ & 29.1 & 34.47 \\
$15 / 01 / 08$ & 28.2 & 34.46 \\
$26 / 01 / 08$ & 27.5 & 34.77 \\
$04 / 02 / 08$ & 26.1 & 34.88 \\
\hline
\end{tabular}


Am. J. Environ. Sci., 5 (3): 455-460, 2009

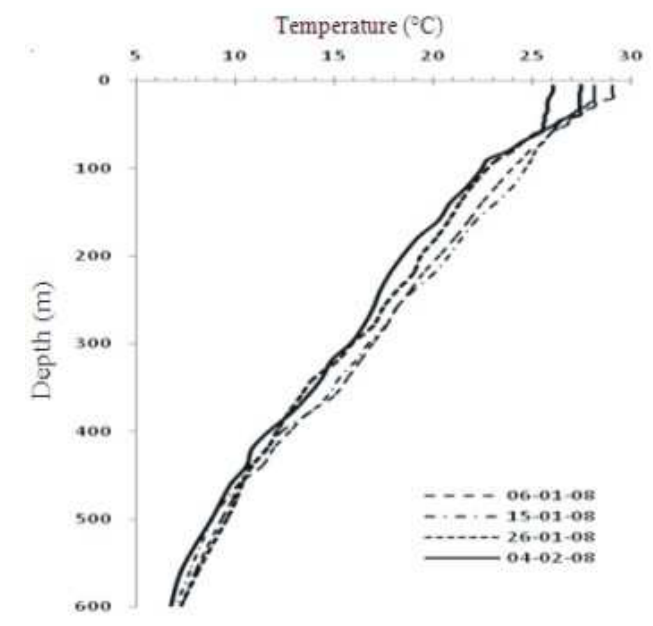

Fig. 3: Temperature profile

Table 2: Mixed layer depth

\begin{tabular}{ll}
\hline Date & Mixed layer depth $(\mathrm{m})$ \\
\hline $05 / 01 / 08$ & 20 \\
$15 / 01 / 08$ & 29 \\
$26 / 01 / 08$ & 38 \\
$04 / 02 / 08$ & 58 \\
\hline
\end{tabular}

Cyclones also affect the deeper structure of the ocean because near the center of the storm, the action of wind causes surface waters to diverge, therefore upwelling occurs and cold water from the sea comes up to replace it. Not only are cyclones affected by the sea surface temperatures but they also modify it, thus cyclone tracks are marked by relatively cold water, about $5^{\circ} \mathrm{C}$ colder $^{[1]}$. Pollard et al ${ }^{[7]}$ stated that cyclones represent one of the most intensive cases of air-sea interaction and that cyclone winds induce strong turbulent mixing in the upper ocean. The entrainment of deep cold water into the mixed layer results in cooling of the mixed layer and deepening of the mixed layer $\operatorname{depth}^{[10]}$.

Amount of heat removed: It is also noticeable that the temperature in the mixed layer decreased by approximately $3^{\circ} \mathrm{C}$ to a depth of about $60 \mathrm{~m}$ before and after TC Gene. This drop in temperature is mainly due to the fact that tropical cyclones are a tool for transporting heat energy towards the poles.

The amount of heat energy removed by TC Gene can be calculated using Eq. 1 with a depth of $60 \mathrm{~m}$ and temperature difference between 26 January and 4 February:

$$
\left.\frac{\Delta \mathrm{E}}{\mathrm{A}}=1022 \times 60 \times(27.5-26.1)=342\right)=342 \mathrm{MJ} \mathrm{m}^{-2}
$$

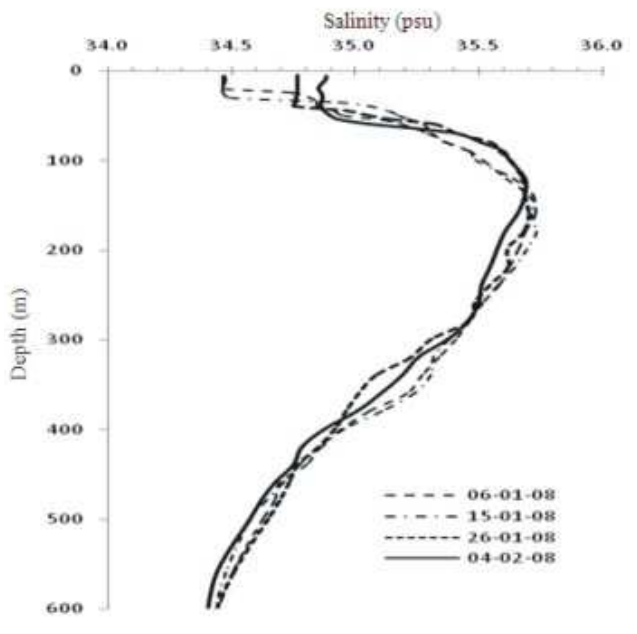

Fig. 4: Salinity profile

Consequently it can be said that from an area of $1 \mathrm{~m}^{2}, 342 \mathrm{MJ}$ of energy was removed:

$$
\text { Energy }=342 \times \frac{1 \mathrm{~h}}{3600 \mathrm{~s}}=0.095 \mathrm{MWH}
$$

From the above calculation, TC Gene could have provided heat energy of $0.095 \mathrm{MWh}$ from just $1 \mathrm{~m}^{2}$ area of sea surface. Taking into consideration that Fiji's annual electricity consumption in 2003 was $628 \mathrm{GWh}^{[6]}$ and if the heat energy from the cyclone could be harnessed (for argument sake), then all of Fiji's power needs would be solved for many years. This hypothetical example clearly indicates the amount of energy which can be removed by a tropical cyclone.

Salinity profiles: Data was used from the same float which was used to plot the temperature profiles. Again emphasis was given to the mixed layer since the wind affected layer (Ekman layer) is only the top part of the ocean.

Figure 4 shows an increase in mixed layer depth after the cyclone (similar values as in Table 2), an increase of approximately $20 \mathrm{~m}$ shifting the halocline layer down. It can be noticed that salinity increased by approximately $0.42 \mathrm{psu}$ after the cyclone in the upper $35 \mathrm{~m}$ of the surface. The increase in sea surface salinity is influenced by turbulent mixing and upwelling of thermocline water ${ }^{[10]}$.

An increase in surface salinity is beneficial because it increases ocean primary (phytoplankton) production. Phytoplankton, besides being the base of the ocean food 
chain, also produces about half the world's oxygen ${ }^{[5]}$. Like all plants, phytoplankton uses carbon dioxide, sunlight and nutrients to photosynthesize and multiply. Thus, primary production also affects the intake of carbon dioxide, an important greenhouse gas and a major cause of natural and man-made climate changes ${ }^{[3]}$.

Lin et $a l^{[5]}$ stated that primary production takes place in the top $50-150 \mathrm{~m}$ of the water column (euphotic zone) where there is abundant light for photosynthesis and the supply of nutrients is mostly from the pumping of nutrient-rich deep water to the euphotic zone through various mechanisms. Thus, the deepening of the mixed layer observed in both the profiles above showing lower temperatures and increased salinity can make the marine environment healthier.

Geostrophic current: Due to the changes noticed in temperature and salinity, the density distribution in the study area also changes. Since variations in the density field give rise to horizontal pressure gradient force, which is represented by the dynamic height, it is worth studying the changes as it affects the geostrophic currents.

The geostrophic current vector map superimposed on the dynamic height topography was used to study the behavior of geostrophic current before and after TC Gene and are shown in Fig. 5.

Figure 5 shows that geostrophic current is directed along the contours of constant height. Note the clockwise and counterclockwise circulation associated with the anticyclonic and cyclonic eddies. The plots in Fig. 5 are used to study the change in dynamic height and geostrophic current patterns.

Comparison was made between Fig. 5c (just before) and Fig. 5d (just after) TC Gene. The area of lower dynamic height shifted at $20^{\circ} \mathrm{S}$ latitude and between 174 and $176^{\circ} \mathrm{E}$ longitudes. Before TC Gene, the southward current was strong in the area. However, the current patterns changed after the cyclone and turned northwards. Similarly, at $175^{\circ} \mathrm{E}$ longitude and between 16 and $18^{\circ} \mathrm{S}$ latitudes, the weak gyre system before the TC was replaced by a strong northward moving current.

Figure 5a-c also show shifting of the lower dynamic height area and consequently the current patterns. These changes are due to the seasonal variation and initial effect of the cyclone. Although TC Gene had a life span of about one week, the variation of the dynamic heights and geostrophic current patterns were evident.

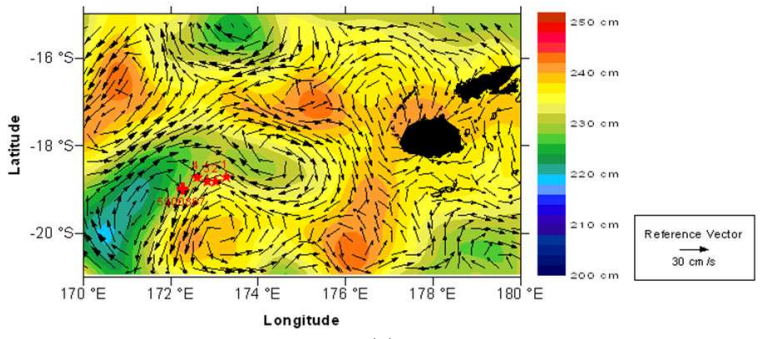

(a)

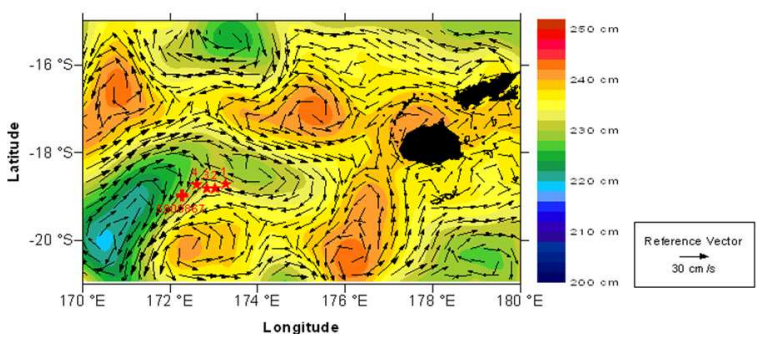

(b)

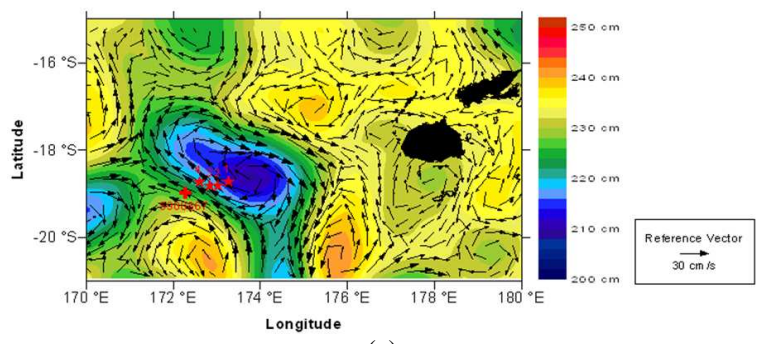

(c)

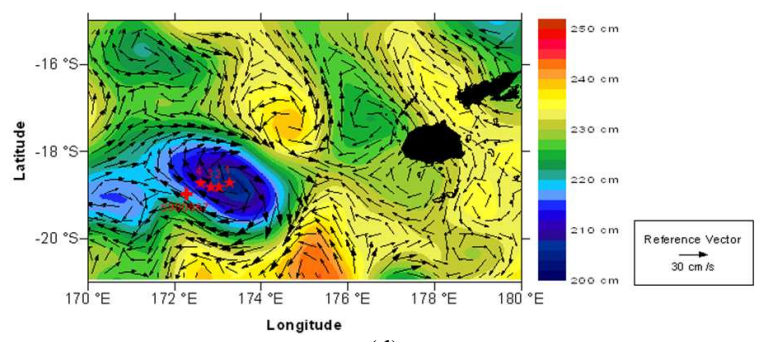

(d)

Fig. 5: Geostrophic currents around Fiji before [(a): 06/01/08; (b): 15/01/08; (c): 26/01/08] and after [(d): 04/02/08] TC gene

\section{CONCLUSION}

From the results obtained, it can be concluded that tropical cyclones significantly modify the oceans temperature and salinity profile to a certain depth (known as the mixed layer). Analysis of the temperature and salinity profiles showed deepening of the mixed layer depth by $20 \mathrm{~m}$. The increase signifies mixing up to a greater depth. This increase in mixed 
layer depth is induced by strong turbulent mixing in the upper ocean and entrainment of deep cold water into the mixed layer which results in cooling of the mixed layer and deepening the mixed layer depth ${ }^{[10]}$.

The surface temperature decreased by $3^{\circ} \mathrm{C}$, which agrees with theory that tropical cyclones take heat from the tropics towards the poles. The amount of heat energy removed by TC Gene was calculated to be 342

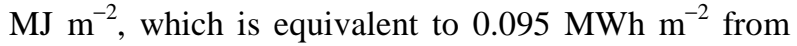
the electrical energy point of view.

The salinity increased by approximately $0.42 \mathrm{psu}$ after TC Gene. This increase can be associated with upwelling of nutrient rich waters due to divergence. The mixed layer depth and salinity increase enhances ocean primary (phytoplankton) production which is the base of ocean food chain and produces about half the world's oxygen ${ }^{[5]}$.

It was noted that TC Gene had significant effect on the dynamic heights and the geostrophic current patterns. Little changes were noticed in the direction of geostrophic currents due to seasonal variations before the cyclone. Although TC Gene life span was not long, it did have some influence on the dynamic heights and geostrophic current patterns in the area near Fiji.

\section{REFERENCES}

1. Brown, J., A. Colling, D. Park, J. Phillips, V. Rothery and J. Wright, 1989. Ocean Circulation. 1st Edn., The Open University Walton Hall, England, ISBN: 0080363695, pp: 238.

2. Davis, R.A. and D.M. Fitzgerald, 2004. Beaches and Coasts. Blackwell Publishing, ISBN: 0632043083, pp: 419.
3. Eppley, R.W. and B.J. Peterson, 1979. Particulate organic matter flux and planktonic new production in the deep ocean. Nature, 282: 677-680. DOI: $10.1038 / 282677 \mathrm{a} 0$

4. FMS., 2008. Fiji islands climate summary February 2008. Fiji Meteorol. Service, 29: 1-5. http://www.wamis.org/countries/fiji/fiji200702.pdf

5. Lin, I., W.T. Liu, C. Wu, G.T.F. Wong, C. Hu, Z. Chen, W. Liang, Y. Yang and K. Liu, 2003. New evidence for enhanced ocean primary production triggered by tropical cyclone. Geophys. Res. Lett., 30: 1718. DOI: 10.1029/2003GL017141

6. Maunsell Limited, 2008. Fiji Electricity Authority (FEA) regulatory review-final report. http://www.sopac.org/data/virlib/PI/PI0075e.pdf

7. Pollard, R.T., P.B. Rhines and R.O.R.Y. Thompson, 1972. The deepening of the wind mixed layer. Geophys. Fluid Dyn., 3: 381-404. http://adsabs.harvard.edu/abs/1972GApFD...4..381P

8. Pond, S. and G.L. Pickard, 1983. Introductory Dynamical Oceanography. 2nd Edn., ButterworthHeinemann Limited, Great Britain, ISBN: 0750624965, pp: 329.

9. Robertson, E.J. and I. Ginis, 1998. The upper ocean salinity response to tropical cyclones. Graduate School of Oceanography, University of Rhode Island, pp: 2.

10. Zenghong, L., X. Jianping, Z. Bokang, S. Chaohui and Z. Lifen, 2006. The upper ocean response to tropical cyclones in the northwestern pacific analyzed with Argo data. Chinese J. Oceanol. Limnol., 25: 123-131. DOI: 10.1007/s00343-0070123-8 